\title{
Yhteisöllistä oppimista wikittämässä
}

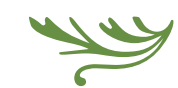

Lapin yliopistossa toteutettiin osa sosiaalityön koulutuksesta verkkokurssina

ja parityöskentelynä. Opiskelijoiden tehtävänä oli kirjoittaa pareittain valitsemastaan sosiaalityön teoriasta wikisivu, joka yhdessä muiden wikisivujen

kanssa muodostavat kurssin lopussa sosiaalityön keskeiset teoriat ja informaatioteknologian soveltamismahdollisuudet teorialähtöisesti esittelevän wikisivuston. Vaiheittaisen kirjoittamisen ja rooliopponoinnin avulla tuotettiin yhdessä sisäistettyä tietämystä ja ymmärrystä opiskeltavista teorioista.

Niin opettajat kuin opiskelijatkin kokivat menetelmän antoisana.

VERKKO-OPETUKSEN SOVELTAMINEN SUUnnitellusti opetuksen yhtenä pedagogisena ulottuvuutena on vielä vakiintumatonta suomalaisessa yliopisto-opetuksessa ja sulautettua opetusta (blended learning) on sisällytetty korkeakouluopetukseen vasta 2000-luvun aikana (Joutsenvirta \& Kukkonen 2009, 5). Lisääntyvästä käytöstä huolimatta sekä sulautetun että verkko-opetuksen käyttö ja kehittäminen jäävät helposti yliopiston muiden muutosten jalkoihin (Levonen \& Joutsenvirta \& Parikka 2009, 20). Niiden käyttö onkin usein riippuvainen yksittäisten henkilöiden tai pienten tiimien motivaatioista kokeilla erilaisia vaihtoehtoja. Parhaimmillaan kasvokkaiseen opetukseen sulautettu verkko-opiskelu mahdollistaa pedagogisesti ajatellen toimivan vuorovaikutuksen opettajien ja opiskelijoiden välille lisäten molemminpuolista oppimista. Samalla myös opetuksen läpinäkyvyys ja avoimuus voivat kasvaa. Oman lisänsä verkko-opetuksen toteuttamisvaihtoehtoihin tuo sosiaalinen media ja sen tarjoamat mahdollisuudet.

Kokeilimme Sosiaalityön informaatioteknologisessa maisterikoulutuksessa (SIMO II) wikin käyttöä perinteisen kasvokkaisen ( $\mathrm{f} 2 \mathrm{f}$-) opetuksen tukena ja täydentäjänä. Artikkelissamme analysoimme kokeilua ja sillä saavutettuja tuloksia.

Lapin yliopisto on yksi Suomen kuudesta yliopistosta, jossa on mahdollisuus opiskella sosiaalityötä. Yliopiston sosiaalityön laitoksen toteuttamana Oulun alueella käynnistyi syksyllä 2008 kolmivuotinen ESR-hanke Sosiaalityön informaatioteknologinen maisterikoulutus ${ }^{1}$. Valtaosa SIMO II:n 25 
opiskelijasta on opintojaan työn ohessa suorittavia aikuisopiskelijoita. Tämä edellyttää joustavuutta niin opintojen aikataulutuksessa kuin suoritustavoissakin. Lisähaasteen opiskeluun tuovat pitkät välimatkat, sillä sekä opettajat että opiskelijat ovat maantieteellisesti etällä toisistaan - opettajat Rovaniemellä ja opiskelijat pääasiassa Oulun alueella. Sulautuva opetus helpottaa työn ja perhe-elämän yhteensovittamista opiskelun kanssa, mutta yksistään sen avulla ongelmia voidaan vähentää vain rajoitetusti. Vaikka ajankäytön joustavuus lisääntyy verkkoa hyödyntämällä, on käytettävissä oleva aikaa yhä niukasti. Opetus tulisikin suunnitella huolellisesti ja rakentaa niin, että verkko-opiskelu on tavoitteellista, tarkoituksenmukaista, selkeästi ohjeistettua ja käytettävä verkkoympäristö on helppokäyttöinen ja selkeä (Matikainen 2009, 27-28). Näihin ehtoihin pyrimme vastaamaan hyödyntämällä verkkoympäristöjä ja sosiaalista mediaa maisterikoulutuksessa mahdollisuuksien mukaan lähiopetuksen lisänä ja täydentäjänä.

\section{TARVE UUSILLE OPETUSMETODEILLE ILMEINEN}

Sosiaalityön aineopintoihin sisältyy Sosiaalityö ongelmanratkaisuprosessina -kurssin seitsemän opintopisteen laajuinen kirjallisuusseminaari. Seminaarin tarkoituksena on tutustuttaa opiskelijat sosiaalityön keskeisiin käytäntöjä ohjaaviin teorioihin, jotka kytkeytyvät ammatilliseen toimintaan ja ongelmanratkaisuprosessiin. Opiskelijat perehtyvät teorioihin avaamalla seminaarityössään teoriaa ja sen sisältämiä käsitteitä sekä soveltamalla teoriaa käytäntöön ennalta valitun tieteellisen artikkelin kautta.

Sosiaalityön opiskelijoilta ja opettajilta vuosien varrelta saatu palaute osoitti kirjallisuusseminaarin muuttamiselle olevan selkeän tarpeen. Seminaarityön kirjoittaminen näytti painottuvan lähelle seminaaritöiden useita päiviä kestäviä purkuistuntoja. Tämäntyyppinen toteutus oli toistuvasti palautteissa todettu rankaksi erityisesti siitä syystä, että omaksuttavaa asiaa kasaantui liian paljon lyhyessä ajassa sisäistettäväksi. Useiden teoriakokonaisuuksien haltuunottoa pidettiin vaikeana ja riskinä oli oppimisen jääminen pinnalliseksi. Myös vertaisoppiminen jäi tavoiteltua vähäisemmäksi. Tämän lisäksi SIMO II -maisterikoulutuksen opiskelijat toistuvasti toivoivat lisää joustavuutta ajankäytössä pystyäkseen paremmin sovittamaan yhteen työn, perheen ja opiskelun vaatimukset.

Palaute, aikaisemmat kokemuksemme ja opiskelijoiden toiveet kannustivat meitä suunnittelemaan kurssille erilaisen toteutustavan. Kurssin sisällöt ja tavoitteet säilyivät lähes entisellään, mutta sen sijaan opetus- ja opiskelutavat sekä kurssin rakenne ja pedagogiset ratkaisut olivat uudistettavissa. Tavoitteena oli vaiheistaa opiskelu siten, että se antaisi opiskelijoille aikaa ja tilaa teorioiden sisäistämiseen. Sosiaalinen media avaa väyliä luoda hyvät edellytykset opiskelijoiden yhteistoiminnalle ja tietämyksen rakentamiselle yhdessä opettajajohtoisen opetuksen sijaan (Niinimäki \& Tenno 2009, 229), joten halusimme kokeilla sen tarjoamia keinoja kirjallisuusseminaarin toteutuksessa. (Kilpeläinen, Sankala \& Päykkönen 2009.)

\section{SUUNNITELMASTA KÄYTÄNTÖÖN}

Aloitimme Sosiaalityö ongelmanratkaisuprosessina -kurssin kirjallisuusseminaarin suunnittelun helmikuussa 2009 ja kurssin uuden toteutuksen pilotointi alkoi syyskuussa 2009. Uudistamistyö käynnistyi tekemällä perinteiselle toteutukselle SWOT-analyysi ja rakenteistamalla kurssin tavoitteet vaiheittain toteutuviksi. Sisällöllisistä muutoksista merkittävimpiin kuului tavoite nostaa informaatioteknologian näkökulma näkyväksi osaksi kurssia maisterikoulutuksen hengen mukaisesti. Punnitsimme erilaisia keinoja ja välineitä kurssin opetuksen uudistamiseksi.

Kurssin suunnittelu konkretisoitui jakamalla maisterikoulutuksen opettajien kesken vastuu uudistamisesta ja tulevasta toteutuksesta: lehtorit miettivät sisältöjen rakenteistamista ja IT-assistentti testasi erilaisia teknisiä toteutusvaihtoehtoja. Lisäksi pohdittavina olivat käytettävissä olevat ajalliset, rahalliset, tiedolliset ja tekniset resurssit sekä mahdollisuudet saada tukea ja neuvoja erilaisiin pedagogisiin ja teknisiin ratkaisuihin. Myös kurssin tulevat opiskelijat otettiin mukaan uudistamistyöhön. Aloitimme heidän sitouttamisen syksyllä toteutettavaan kurssiin jo loppukeväästä. Kerroimme heille tulevasta opetuskokeilusta, jolloin he saivat myös kurssin alustavan rakenteen sisältöineen tutustuttavaksi ja kommentoitavaksi. Opiskelijoiden palaute jäi kuitenkin vähäiseksi vielä tässä vaiheessa. 
Päätavoitteemme olivat helpottaa opiskelijoiden ajanhallintaa ja vaativan teoreettisen oppiaineksen sisäistettävyyttä. Jaoimme kirjallisuusseminaarin seitsemään moduuliin, joista ensimmäinen ja viimeinen olivat lähiopetusta ja keskimmäiset verkkotyöskentelyä. Opiskelijat siirtyivät opintomoduulista toiseen etukäteen määriteltyjen ajanjaksojen aikana, mutta moduulien sisäiset opiskeluajat olivat heidän itsensä päätettävissä. Muutaman päivän kestävien siirtymäjaksojen aikana opiskelijat antoivat ja saivat palautetta toisiltaan verkon kautta.

Lähiopetuksen ensimmäisenä päivänä kerroimme kurssin tavoitteet ja sisällön opiskelijoille sekä tutustutimme opiskelijat opiskelumetodiin. Pareittain toteutettavaan verkkotyöskentelyyn kukin pari valitsi yhden sosiaalityön keskeisistä teorioista opiskeltavakseen. Työpareille nimettiin opponoitavat teoriat. Opponointi toteutettiin verkossa rooliopponointina eli opiskelijat saivat opponoidessaan asettautua joko kyseenalaistavan tai ihmettelevän sosiaalityöntekijän tai asiakkaan rooliin. Mikäli joku halusi, opponointiroolin sai määritellä myös itse. Ainoana ehtona oli, että oma opponoijarooli ilmoitettiin tekstin alussa, jotta kirjoittaja voi asemoida opponoinnit suhteessa kommentoijan rooliin. Näiden etukäteen valittujen roolien kautta opiskelijat saivat kommentoida ja esittää kysymyksiä opponoitavana olevasta työstä.

Sisältöjen ohella teknologisiin ratkaisuihin perehtyminen oli osa kurssin avausjaksoa. Toisena lähiopetuspäivänä harjoittelimme kurssilaisten kanssa tiedostojen jakamista, yhdessä muokkaamista ja kommunikointia tukevien verkkopalvelujen käyttöä. Opiskelijoilla on maisterikoulutuksen puolesta käytössään kannettavat tietokoneet, joihin työparit asensivat lähiopetuksessa esitellyistä ohjelmista työskentelyään tukemaan valitsemansa vaihtoehdot. Yhteistoiminnallista oppimista tukeviksi ohjelmistoiksi ja palveluiksi kurssille tarjottiin ilmaiseksi käytettävissä olevat DropBox, Google Docs ja Live Messenger. Kirjallisuusseminaarityön kirjoittamis- ja julkaisualustaksi valittiin Wikispaces-palveluun kurssia varten perustettu wiki, johon kukin työpari sai oman wikisivun työstettäväkseen. Wikiin kirjoittamista ja toisten työparien kirjoitusten kommentointia harjoiteltiin ohjatusti lähiopetuksessa, jotta etätyöskentely sujuisi kitkattomasti. Wiki valittiin kurssille, koska halusimme kokeilla uutta työskentelyalustaa ja samalla tutustuttaa opiskelijat nopeaan ja ilman aikaisempaa kokemusta onnistuvaan verkkojulkaisemiseen. Wikin eduiksi näimme vuorovaikutteisuuden, muutosten teon helppouden sekä muutosten jäljitettävyyden.

\section{YHTEINEN OPPIMISPROSESSI NÄKYVÄKSI}

Opiskelijoiden tehtävänä kurssin aikana oli kirjoittaa pareittain valitsemastaan sosiaalityön teoriasta wikisivu, jotka yhdessä muodostaisivat kurssin lopussa sosiaalityön keskeiset teoriat ja informaatioteknologian soveltamismahdollisuudet teorialähtöisesti esittelevän wikisivuston. Tavoitteena oli vaiheittain kurssin aikana täydentyvä, yhdessä pohdittu ja luotu tieteellinen teksti "omasta teoriasta" muille työpareille tutustuttavaksi ja kommentoitavaksi.

Kirjoittaminen eteni moduuleittain niin, että kunkin moduulin lopussa opponoijat kommentoivat opponoimansa parin kirjoituksia wikin keskustelutoiminnon kautta. Vaiheittaisen etenemisen tarkoituksena oli "pilkkoa elefantti syötäviin osiin", jäsentää laaja ja vaikeasti hahmotettava kokonaisuus helpommin sisäistettäväksi. Vaiheittaisen kirjoittamisen ja palautteen avulla tavoitteena oli tuottaa yhdessä työskentelemällä sisäistettyä tietämystä ja ymmärrystä opiskeltavista teorioista. Huomioitavaa oli myös se, että opiskelijat näkivät koko ajan, miten toiset ryhmät rakensivat omia töitään, minkä oli todettu edellisessä SIMO-maisteriohjelmassa saatujen kokemusten mukaan toimivan hyvänä kannustimena aktiivisuuteen ja yhdessä opiskeluun verkon välitykselläkin (Päykkönen \& Salo-Laaka 2008, 107). Vaikka työparit seurasivat toisten töitä koko kirjoittamisprosessin ajan, tuli jokaisen parin työstä hyvin yksilöllinen omine sisältöineen ja rakenteellisine ratkaisuineen.

Aikaisempiin kirjallisuusseminaarin toteutuksiin verrattuna opetuskokeilussa korostui lopputuotoksen rinnalla enemmän itse oppimisprosessi. Opiskelijoiden itseohjautuvuus ja itsetuntemus näkyivät aiempaa enemmän tehden heidät vastuullisiksi omasta ja opiskelutovereittensa oppimisesta. Kehysaikataulussa pysyminen sitoi opiskelijoita pitämään annetuista ajoista kiinni, jolloin opiskelu eteni ja ymmärrys syveni jakso jaksolta. 
"Aikataulutus toimi kivasti: hommat tulee tehtyä, kun ne on jaettu eri ajanjaksoille." (Opiskelijapalaute 2009)

Yhtenä kannustavana tekijänä oli myös yhdessä tekeminen individualistisen tiedon omaksumisen sijaan. Yhdessä opiskelu pakotti perustelemaan ajatuksiaan täsmällisemmin sekä samalla sai omille ajatuksilleen palautetta lähes reaaliajassa.

Kokonaisuudessaan kirjallisuusseminaarityöskentely kesti vajaat kaksi kuukautta. Kurssin jakaminen moduuleihin ja välitavoitteisiin oli onnistunut ratkaisu, sillä se pakotti ryhmät työskentelemään tasaisesti koko työskentelyajan ja poisti mahdollisuuden lykätä työskentelyn aloittamista viime hetkeen. Rakenteistettu yhdessä kirjoittaminen tuki sisäistävää oppimista: opiskelijoiden teksteissä näkyi oma pohdinta ja oivaltava ajattelu. Odotetusti oman teorian sisäistäminen onnistui parhaiten. Sen lisäksi opponoitava teoria avautui, mutta muutkin tarkasteltavina olleet teoriat tulivat ymmärretyiksi.

"Oma ja opponoitava alue tulivat eniten tutuiksi. Kaikkiin töihin oli arvioinnin takia paneuduttava, mikä oli hyvä asia. Näin sain kaikista alueista jonkinlaisen ymmärryksen." (Opiskelijapalaute 2009)

Roolien kautta tapahtunut opponointi tuotti rakentavia kommentteja, joissa näkyivät sekä annettu opponointirooli että opiskelijan oma mielipide. Rakentava palaute opponoijilta auttoi opiskelijoita jatkamaan wikisivunsa työstämistä.

Prosessinomaisella kirjoittamisella tavoiteltiin kriittistä ja oivaltavaa ajattelua. Teorioiden soveltaminen käytäntöön onnistuikin varsin hyvin. Kurssin oppimateriaaliksi annettujen lähteiden lisäksi opiskelijat käyttivät runsaasti oheislähteitä; heillä heräsi halu avartaa ja syventää oman teorian ymmärtämistä. Opponointi vaikutti herättäneen mielenkiintoa asiakokonaisuutta kohtaan, pohtimista ja tiedonhalua. Opiskelijoiden töiden sisällöistä esiin nousivat sosiaalityön uudenlainen asiakkuus, asiantuntijuus, yhteisöt ja rakenteellinen sosiaalityö.

Usein rankassa ja vaativassa maisteriopintojen työn ohessa opiskelussa työn yhdessä pohtiminen ja tekeminen toivat oppimiseen iloa. "Oman teorian" lisäksi muut teoriat tulivat tutuiksi opponoinneissa sekä kurssin loppuvaiheessa toisten töistä heille palautetta antamalla. Opiskelijat myös kannustivat toisiaan suorituksiin sekä antoivat positiivista palautetta toisilleen.

"Hyvä Simolaiset! Me selvittiin tästä kurssista." (Opiskelijapalaute 2009)

\section{YHTEISÖLLISYYS SYNTYI MONITASOISISSA RYHMISSÄ}

Kurssilla opiskelijaparit muodostivat oman pienen ryhmän, opponointiparit muodostivat toisen ja kolmas ryhmä muodostui jokaisesta kurssille osallistuvasta ryhmästä. Kurssin toteutus rakentui siis pitkälti ryhmien toiminnan varaan sisältäen vahvan koulutuksellisen komponentin. Kurssin kokonaistavoite oli tiedon saaminen sekä taidon tai taitojen oppiminen sosiaalityön käytänteitä ohjaavista teorioista sekä myös tiedon yhdisteleminen omaan kokemusmaailmaansa ryhmän yksilöllisen teeman kautta. Prosessi oli strukturoitu ja tavoitteellistettu kolmeen keskeiseen ydinalueeseen: tiedon löytymiseen, tiedon omaksumiseen sekä ymmärryksen lisäämiseen.

Opiskelijat liikkuivat ja suhteuttivat toimintaansa eri ryhmien välillä ja kesken ennakkoon määritellyn prosessin aikana. Normaalista oppimisprosessista poiketen yksittäinen opiskelija pystyi siis hyödyntämään pariansa sekä toisia ryhmiä tiedon hankinnassa tehokkaammin kuin perinteisessä kirjallisuuteen pohjautuvassa tiedonhankinnassa. Opettajan näkökulmasta katsottuna ja suhteutettuna oppimistuloksiin tiedon omaksumisessa eli teorioiden sisäistämisessä onnistuttiin. Tiedon löytymisessä ja omaksumisessa edesauttoi mallioppiminen: ryhmät seurasivat usein sitä, miten joku toinen ryhmä rakensi omaa teoriaansa wikissä ja ammensivat siitä omaan teoriaansa sopivia näkökulmia. Toisaalta myös ryhmät opponoinnin kautta saivat ideoita sisäistämiseen.

Ryhmien valmiissa seminaaritöissä, opponoinneissa ja seminaarikeskusteluissa näkyi tiedon ja teorioiden liittäminen ja peilaaminen omaan opiskelijan yksilölliseen kokemusmaailmaan. Omasta kokemushistoriasta tunnistettiin ja löydettiin esimerkkejä selittämään tai tukemaan omaa teoriaa ja 
toisaalta myös toisen ryhmän teoriaa, mikä näkyi opponoinneissa. Olisi todella mielenkiintoista tutkia tarkemmin sitä, minkälaisia suhteita rakentuu tällaisen toiminnan aikana ryhmien sisällä, välillä ja suhteessa opettajaan, toisaalta myös jaksolle asetettuun tavoitteeseen suhteutettuna.

Moduulit loivat rajat ryhmien työskentelyvaiheiden aluille ja lopuille. Niiden sisään oli rakennettu moduulikohtaisia kehysaikatauluja takarajoineen, jolloin esimerkiksi käsiteltävän teoria keskeiset käsitteet piti olla muiden luettavissa. Sen sijaan moduulien sisällä aikataulut olivat joustavia mahdollistaen ryhmien opiskelun sovittamisen muuhun elämään. Koska etukäteen nimetyillä opponointiryhmillä piti olla opponoitavaa sovittuina aikoina ja opponoinnit valmiina määräaikaan mennessä, toimi vertaiskuri aikataulujen noudattamisessa. Ryhmät huolehtivat itsenäisesti työvaiheiden takarajoista ja myös huomauttivat toisilleen, jos jokin ryhmä ei pysynyt aikataulussa. Keskinäiseen vastuun jakamiseen ei opettajien tarvinnut erikseen kiinnittää huomiota.

\section{SOSIAALISEN MEDIAN HAASTEITA OPPIMISELLE JA OPETUKSELLE}

Sosiaalista mediaa olisi voitu hyödyntää monipuolisemminkin, mutta aloitimme varovasti ja rajoituimme kurssilla pelkästään wikin käyttöön. Siitä huolimatta ajoittaiset tekniset ongelmat toivat omat ongelmansa yhdessä kirjoittamiselle. Ilmaisen wikipalvelun ajoittainen toimimattomuus vaati opiskelijoilta kärsivällisyyttä, mutta opetti myös varmuuskopioiden ja tiheän tallentamisen merkityksen - joillekin kantapään kautta. Myös kirjoitusten ulkoasu vaihteli yllättävän paljon, sillä esimerkiksi kirjasintyyppi vaihteli näennäisen sattumanvaraisesti kopioitaessa tekstinkäsittelyohjelmalla muotoiltua tekstiä wikiin. Tämä ongelma olisi voitu kiertää ohjeistamalla opiskelijat joko liittämään pelkästään muotoilematonta tekstiä tai tuottamaan wikisivunsa suoraan wikin tekstieditorilla, mutta wikipalvelun käyttökatkosten ja yhteydenmuodostusongelmien vuoksi jälkimmäinen vaihtoehto oli mahdoton toteuttaa. Verkkotyöskentelyssä tuli korostuneesti esiin opiskelijoiden eri vaiheessa olevat tietotekniset valmiudet. Kun ilmaispalvelut eivät aina toimineet kaikkein luotettavimmalla ja helppokäyttöisimmällä tavalla, opiskelijat turhautuivat ja kaipasivat toimivampia vaihtoehtoja.

Uusilla menetelmillä toteutettu opiskelu osoittautui mielenkiintoiseksi, mutta toisaalta vaativaksi tavaksi oppia laajoja kokonaisuuksia. Vahvasti itseohjautuvuuteen pohjautuva opiskelu edellyttää osallistujilta itsekuria ja ajankäytön hallintaa. Joustava aikataulu oli selkeästi etu, mutta oman aikansa vaativat myös pohtiminen sekä teorian ja käsitteiden sisäistäminen. Tämän huomioon ottaminen kurssin mitoituksessa vaatii jatkopohdintaa.

Kurssin toteutus päättyi seminaari-istuntoihin, joissa jokainen työpari vielä tiivistetysti kertoi omasta teoriastaan pohjustaen ryhmäkeskustelua. Tämä "purkuseminaari" olisi palvellut oppimista ja asioiden sisäistämistä toteutettua järjestystä paremmin, mikäli sen paikka olisi ollut ennen synteesin kirjoittamista.

"Seminaarit olisi ollut hyvä pitää ennen synteesin kirjoittamista." (Opiskelijapalaute 2009)

Purkuseminaarin keskustelut herättivät osallistujissa oivalluksia, joiden kirjoittaminen synteesiin olisi syventänyt opiskelijoiden ymmärrystä sekä omasta että toisten teorioista. Tämän näkemyksen jakoivat sekä opettajat että opiskelijat.

Opettajille uusien menetelmien kokeilu on antoisaa, sillä se tarjoaa kehittämis- ja kehittymismahdollisuuksia. Ennakko-oletuksemme kurssin sisällöllisen uudelleenarvioinnin tarpeesta vahvistui entisestään ja toisaalta muutamat teoriaosuudet sisälsivät useita valinnan mahdollisuuksia, jolloin jo aiheeseen tarttuminen vaatii opiskelijoilta vähintäänkin pinnallista perehtymistä useaan teoriasuuntaukseen. Jotta opiskelijoiden syvällisemmän ymmärryksen saaminen omasta teoriasta mahdollistuisi entistä paremmin, olisi nyt olemassa olevia teoriavaihtoehtoja avattava enemmän ja joiltain osin täsmennettävä.

Verkko-opiskelu toi esiin myös kysymyksen opettajan roolista sekä läsnäolon määrästä ja tarpeesta työskentelyn eri vaiheissa. Opettajina olimme tehneet valinnan, että tarkkailemme wikisivujen kirjoittamisprosessia ja seuraamme töiden etenemistä säännöllisesti, mutta pidämme läsnäolomme mahdollisimman näkymättömänä. Wikityöskentelyn ai- 
kana oli useita kohtia, joihin opettajina olisimme voineet tarttua, mutta tietoisesti jätimme sen tekemättä. Jatkossa yhteisöllistä oppimista hyödyttää varmasti se, että myös opettajat ovat aktiivisempia itsenäisen työskentelyn aikana. Tätä toivoivat myös opiskelijat:

"Olisko opettajat voineet antaa palautetta Wikissä töiden edetessä?" (Opiskelijapalaute 2009)

Aktiivinen läsnäolo tukee opiskelijoiden töiden etenemistä, mutta myös opettajat ovat yhteisöllisessä oppimisessa opiskelijan roolissa. Opiskelijat näkivät paljon vaivaa muun muassa kurssikirjallisuuden ulkopuolelta tulevan taustamateriaalin hyödyntämisessä lisäten sitä kautta kaikkien oppimista. Jaettu opiskelu tuotti oivalluksia, joiden syntyminen olisi ollut kyseenalaista yksittäisen opiskelijan tai opettajan tuottamana (ks. myös Paavola \& Hakkarainen \& Seitamaa-Hakkarainen 2006, 147).

Työskentelyyn valittu rooliopponointi osoittautui onnistuneeksi ja toimivaksi tavaksi kommentoida opiskelijakollegoiden töitä. Rooliopponoinnin ilmeinen etu oli se, että opiskelija pystyi antamaan palautetta toisille roolin kautta, ei omana itsenään, jolloin vältettiin palautteen henkilöityminen opiskelijaan itseensä; kriittistäkin palautetta on helpompi antaa roolin suojista. Opiskelijoiden uiminen sisälle opponointirooliin oli helppoa ja toisaalta rooliopponointikommentit otettiin vastaan roolin tuottamina, ei opiskelijakaverin antamana palautteena.

\section{POHDISKELEVAA YHTEENVETOA}

Erilaisten toimintamallien kehittäminen ja toteuttaminen opetuksessa vaatii sekä opettajilta että opiskelijoilta joustavuutta ja halua kokeilla uusia vaihtoehtoja. Kirjallisuusseminaarin toteuttamiseen valitsemamme wiki näytti meille sekä hyvät että huonot puolensa jo ensimmäisessä kokeilussa.

Wikin kautta toteutettu yhteisöllinen oppiminen tuotti muutakin kuin olemassa olevan tiedon toistamista ja välittämistä. Yhdessä työskentely verkkovälitteisesti ja lähiopetuksena tuotti uudenlaista tietoa ja ymmärrystä sosiaalisen vuorovaikutuksen myötävaikutuksella. Vaikuttaa siltä, että yhteisesti tuotettu oppiminen lujitti mukana olleiden yhteisöllisyyttä ja lisäsi heidän taitojaan sekä antaa että ottaa vastaan kirjallista ja suullista palautetta. (Ks. Arvaja \& Mäkitalo-Siegl 2006, 125-140.)

Opiskelijoiden palaute oli lähes kauttaaltaan positiivista. Kurssia pidettiin tähänastisten sosiaalityön opintojen kursseista onnistuneimpana. Rooli-opponointia pidettiin hyvänä, sillä se rajasi näkökulmaa, josta opiskelija tarkasteli opponoitavaa työtä ja antoi siitä huolimatta tilaa mielikuvitukselle ja valtaa opiskelijalle itselleen. Lopputuloksena opiskelijat onnistuivat erinomaisesti kurssin tavoitteisiin nähden.

Opettajan näkökulmasta tarkastellen valta-asetelmien tiedostaminen oli yksi kriittisiä pisteitä kurssin toteuttamisessa. Opiskelijan itseohjautuvuus edellyttää opettajalta luopumista ainakin osasta valtaa. Kuitenkin opettajan on oltava läsnä ja osattava ratkaista, milloin opiskelijoiden itseohjautuvuus tukee oppimisprosessia ja milloin se mahdollisesti heikentää sitä. Opettajan on syytä miettiä erittäin tarkkaan mitä, miksi ja milloin osallistuu kysymyksin, kommentein tai neuvoin verkossa käytävään keskusteluun. Ryhmädynamiikan toiminta oppimisen tukena osoittautui kurssilla hyväksi, mutta entäpä, jos kurssin aikana olisi tullut ryhmän sisäisiä konflikteja tai muita vastoinkäymisiä?

Opettaja joutuu myös miettimään omien toimintatapojensa uudistamista ja muuttamista. Prosessikirjoittaminen edellyttää säännöllistä läsnäoloa, vaikkakin mukanaolo voi olla opiskelijalle näkymätöntä. Toisaalta tämä helpottaa opettajan työskentelyä: hän on koko ajan tietoinen siitä, missä vaiheessa opiskelijat ovat kirjoittamisessaan, ja voi tarvittaessa ohjata opiskelijoita jo kirjoitusprosessin aikana.

Parannettavaa kurssin toteutuksessa jäi eniten aikataulutukseen. Lopun seminaarissa saatujen kommenttien jälkeen opiskelijat olisivat tarvinneet vielä aikaa oppimansa hiomiseen viimeistellyksi tekstiksi sen sijaan, että synteesi kirjoitettiin valmiiksi ennen seminaaria. Myös kurssin kokonaisaikataulu olisi voinut olla löysempi, jotta aikaa ajattelulle olisi jäänyt enemmän.

Teknologiaorientoitunut työskentely asettaa omat haasteensa opintokokonaisuuksien toteuttamiselle. Vähimmäisvaatimuksena lienee se, että opettaja itse on perehtynyt käytettäviin alustoihin, jotta työskentely etenee sujuvasti. Opettajatiimissä täytyy olla 
joku, joka tunnistaa teknologian mahdollisuudet, mutta myös sen tuomat rajat ja reunaehdot työskentelyyn. Opiskelijat ainakin ovat valmiita ja motivoituneita tämänkaltaiseen työskentelyyn.

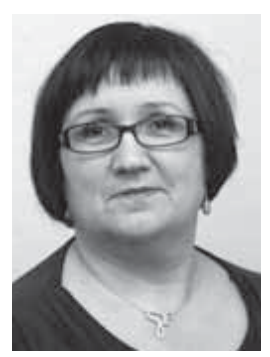

Arja Kilpeläinen,

yliopisto-opettaja,

Lapin yliopiston

sosiaalityön laitos

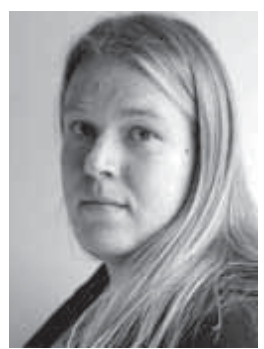

Kirsi Päykkönen, yliopisto-opettaja, Lapin yliopiston sosiaalityön laitos

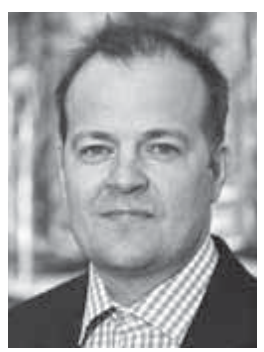

Jukka Sankala,

laatupäällikkö,

Lapin yliopiston

sosiaalityön laitos
Kilpeläinen, A. \& Sankala, J. (2009). Information technology (IT) as a tool to improve education of social work in Northern Finland. Oral presentation. Ensact (European Network for Social Action). Dubrovnik, Croatia 26.-29.4.2009.

Kilpeläinen, A., Sankala, J. \& Päykkönen, K. (2009). Sosiaalinen media kirjallisuusseminaarityöskentelyssä. Virtuaalikorkeakoulupäivät 18.-19.11.2009, Espoo.

Levonen, J., Joutsenvirta, T. \& Parikka, R. (2009). Blended Learning - katsaus sulautuvaan yliopistoopetukseen. Teoksessa Joutsenvirta, T. \& Kukkonen, A. (toim.) Sulautuva opetus - uusi tapa opiskella ja opettaa. Helsinki: Gaudeamus, 15-23.

Matikainen, J. (2009). Maisteriohjelma verkossa - verkkoviestinnän muuntokoulutus Wermu. Teoksessa Joutsenvirta, T. \& Kukkonen, A. (toim.) Sulautuva opetus - uusi tapa opiskella ja opettaa. Helsinki: Gaudeamus, 25-36.

Niinimäki, J. \& Tenno, T. (2009). Sosiaalinen media ammatillisessa opetuksessa - ammatillisten opettajakorkeakoulujen opettajaopiskelijoiden opetuskäytänteitä. Aikuiskasvatus 29(3), 229-235.

Paavola, S., Hakkarainen, K. \& Seitamaa-Hakkarainen, P. (2006). Tutkivan oppimisen periaatteita ja käytäntöjä: "trialoginen" tiedonluomisen malli. Teoksessa Järvelä, S., Häkkinen, P. \& Lehtinen, E. (toim.) Oppimisen teoria ja teknologian opetuskäyttö. Helsinki: WSOY, 147-180.

Päykkönen, K. \& Salo-Laaka, M. (2008). Tieteidenvälinen opetus - pedagogisia ratkaisuja etsimässä. Teoksessa Poikela, E. \& Poikela, S. (toim.) Laatua opiskeluun. Rovaniemi: Lapin yliopistokustannus, 96-109.

\section{KIRJALLISUUS}

Arvaja, M. \& Mäkitalo-Siegl, K. (2006). Yhteisöllisen oppimisen kognitiiviset, sosiaaliset ja kontekstuaaliset tekijät: verkkovuorovaikutuksen näkökulma. Teoksessa Järvelä, S., Häkkinen, P. \& Lehtinen, E. (toim.) Oppimisen teoria ja teknologian opetuskäyttö. Helsinki: WSOY, 125-146.

Hankehakemus. (2007) Hakemus rahoituskaudelle 17.8.2008-31.10.2011. Julkaisematon lähde.

Joutsenvirta, T. \& Kukkonen, A. (2009). Esipuhe. Teoksessa Joutsenvirta, T. \& Kukkonen, A. (toim.) Sulautuvaa opetusta monilla tavoilla ja menetelmillä. Verkkojulkaisu. http://www.helsinki. fi/valtiotieteellinen/julkaisut/sulautuva_opetus.pdf. Viitattu 27.1.2010.

\section{VIITE}

1 Hankkeen rahoittajaviranomainen on Pohjois-Pohjanmaan elinkeino-, liikenneja ympäristökeskus. Keski- ja PohjoisPohjanmaalla vaikuttavaa koulutusta rahoittavat kuntaosuuksillaan Oulun seudun kunnista Oulu, Haukipudas, Kempele, Kiiminki, Oulunsalo, Muhos, Liminka, Tyrnävä, Lumijoki ja Hailuoto. (Hankehakemus 2007; Kilpeläinen \& Sankala 2009.) 